Egyptian Poultry Science Journal

http://www.epsaegypt.com

ISSN: 1110-5623 (Print) - 2090-0570 (On line)

\title{
AN ATTEMPT TO IMPROVE SOME PRODUCTIVE, REPRODUCTIVE AND PHYSIOLOGICAL PERFORMANCE OF MALE AND FEMALE AGED INSHAS STRAIN LAYING HENS BY USING ZINC METHIONINE.
}

A.K. Alm El-Dein* - M.M. Soliman* - A.M.Rezk* - M. A. Khattab ${ }^{* *}$ - S.M.M. Mousa*

*Dep. of Poul. Breeding Res., Anim. Prod. Res. Inst., Agric. Res. Cent., Minist. of Agric., Dokki, Giza, Egypt.

** Dep. of Cyt. and Hist., Fac. of Veter. Medic., Cairo Uni., Giza, Egypt. Corresponding author: Alaa Alm El-Dein, Email: alaa.alm010@gmail.com

Received:17/12/2016

Accepted:17/01/2017

ABSTRACT:This work was carried out to study the effect of dietary Zinc methionine supplementation on some productive, reproductive and physiological performance traits of aged male and female Inshas strain laying hens. A total number of 150 laying hen plus 15 cockerels of Inshas strain at 48 weeks of age were used in this experiment up to 60 weeks of age. All birds were randomly divided into five equal groups each of 30 females and 3 males, with three equal replicates, wing banded and individually weighed, with nearly similar average initial live body weight of all groups. The 1st group (T1) was fed the basal diet contained $50 \mathrm{mg}$ Zinc oxide/ $\mathrm{kg}$ diet according to NRC, (1994), and served as control, while $2^{\text {nd }}, 3^{\text {rd }}, 4^{\text {th }}$ and $5^{\text {th }}$ groups (T2, T3, T4 and T5 respectively) were fed the basal diet supplemented with 40, 60, 80 and $100 \mathrm{mg}$ Zinc methionine/kg diet ,respectively. Final body weight, body weight gain, egg production percentage, shell thickness and shell weight percentage were significantly $(\mathrm{P} \leq 0.05)$ improved for birds fed diet supplemented with Zinc methionine at levels 60,80 and $100 \mathrm{mg} / \mathrm{kg}$ diet and albumen weight percentage at levels $40,60,80$ and $100 \mathrm{mg} / \mathrm{kg}$ diet compared to those fed the control diet. Gradual increase had been observed in plasma hemoglobin (Hb), red blood cells (RBCs), hematocrit, white blood cells (WBCs), lymphocyte percentage, testosterone, estrogen, progesterone and Zinc ( $\mathrm{Zn})$ concentrations and gradual decrease in plasma heterophill/lymphocyte ratio, phosphorus $(\mathrm{P})$, Copper $(\mathrm{Cu})$ and Iron $(\mathrm{Fe})$ concentrations with increasing dietary levels of Zinc methionine compared to control group. Linear increase was observed in some semen quality traits \{ejaculate volume (E.V), sperm concentration (S.C), live sperm percentage (L.S\%), sperm motility (S.M), total sperm per ejaculate(TS/E) and total live sperm per ejaculate (TLS/E) $\}$, as well some histomorphological parameters of male testicular tissues (Germinal epithelium thickness and seminiferous tubular diameter), relative testes weight, relative oviduct weight, fertility percentage, hatchability percentage of total eggs and hatchability percentage of fertile eggs were linearly increased but, abnormal sperm percentage (Ab.S\%) and total abnormal sperm per ejaculate (TAbS/E) were linearly decreased as the levels of Zinc methionine in cocks diet increased compared to cocks of control group. Data from the current study concluded that adding zinc methionine up to $100 \mathrm{mg} / \mathrm{kg}$ diet could be used as an efficient tool for improving productive, reproductive and physiological performance of male and female aged Inshas strain laying hens.

Key words: Zinc methionine, Productive, Reproductive, Physiological Traits. 


\section{INTRODUCTION}

The free radical theory of aging is one of the most popular theories of aging, which demonstrated increasing generation of free radical as the major cause of cellular damage (Harman, 1992). Because it doing lipid peroxidation which is associated with a progressive loss in membrane fluidity, reduction in membrane potential, increase in membrane permeability to ions which finally leads to cellular damage ( $\mathrm{Yu}$ and Yang, 1996). Elevated levels of lipid peroxidation are responsible for the decreased physiological performance and increased susceptibility to age-associated diseases like as Alzheimer's disease and Parkinson's disease (Schipper, 2004). The oxidant-antioxidant status can vary between mammalian and birds because the birds have higher levels of blood uric acid than mammalian (Klasing, 1998). The reproductive performance in female birds is known to deteriorate with age and is closely connected with endocrine changes, primarily with variations in circulating levels of gonadotropins and sex steroid hormones (Burger et al., 2002). In males, an atrophy of testes seminiferous epithelial were occurred at 60 weeks of age in Japanese quail (Ottinger and Gorham, 1986) and lipid peroxidation of the long chain polyunsaturated fatty acids in the sperm cell membrane which is the primary cause of infertility in turkey (Cecil and Bakst, 1993).

Zinc is a hydrophilic metal which is found in the structure of more than 300 enzymes and molecules in the body and participates directly in enzyme catalysis, if the metal is removed by chelating or other agents, the enzyme becomes inactive (Vallee and Falchuk, 1993). Also, it is an essential element in many physiological functions including growth, immune response, reproduction, and antioxidant defense (McDowell, 1992). Zinc is traditionally supplemented in layer feeds by using inorganic sources, such as Sulfates or
Oxides with recommended level $(50 \mathrm{mg} / \mathrm{kg}$ diet) for laying hens according to (NRC, 1994). However, these sources have variable bioavailability, Zinc sulfate (acid salts) are highly water soluble, allowing reactive metal ions to promote free radical formation, this reaction can lead to the breakdown of vitamins and ultimately to the degradation of fats and oils and decreasing the nutritive value of the diets, which can impair bird performance and may contribute to environmental pollution while, Zinc oxides are less reactive but also less bioavailable (Edwards and Baker. 1999). Recently, organic sources with the inorganic minerals are commonly used in animal nutrition in order to avoid the disadvantages of the inorganic sources of minerals (Boruta et al., 2007).

Therefore, The present study was conducted to determine the effect of adding different levels of organic Zinc (Zinc methionine) to formula of laying hen's diet basically contain $50 \mathrm{mg}$ Zinc oxide/kg diet, as a source of inorganic Zinc, according to (NRC, 1994), on some productive, reproductive and physiological performance of aged male and female Inshas strain laying hens.

\section{MATERIALS AND METHODS}

This experiment was carried out at Inshas Poultry breeding Station, Animal Production Research Institute, Agricultural Research Center.

\section{Experimental design}

A total number of 165 Inshas strain birds (150 hens and 15 cocks) 48-wks-old were used in this experiment up to 60 wks of age. All birds were individually weighed and randomly divided into 5 equal experimental groups ( 30 hens and 3 cocks of each) with three replicates (10 hens and 1 cock each) with almost similar initial average body weight. Replicates were randomly housed in floor pens $(280 \mathrm{~cm}$ long x $220 \mathrm{~cm}$ wide). The first group was fed the basal diet contained $50 \mathrm{mg}$ Zinc oxide/kg diet according to NRC (1994), 
and served as control. The second, third, fourth and fifth groups were fed the basal diet supplemented with 40, 60, 80 and 100 $\mathrm{mg}$ Zinc methionine/kg diet, respectively.

Management and feeding:

All birds were kept under the same managerial hygienic and environmental conditions. Birds were kept in a windowed house with light cycle regimen of $16 \mathrm{~h}$ light: $8 \mathrm{~h}$ darkness, throughout the experimental period (4860 wks of age). Feed and water were provided for ad libitum consumption. Birds were fed layer diets according to NRC (1994). The composition and calculated analysis of the basal diet ( Table 1 ) showed the adequacy of all nutrients needed for laying hens.

\section{Measurements:-}

\section{Laying performance traits:}

Body weights were recorded at the beginning (48 weeks of age) and the end of the experiment ( 60 weeks of age). Feed intake and feed conversion ratio, egg number and egg production percentage, egg weight and egg mass (number of eggs $\mathrm{x}$ egg weight) were recorded for each replicate at the end of each week from 48 up to $60 \mathrm{wks}$ of age.

\section{Egg quality parameters:}

A total of 75 eggs (15 eggs from each treatment) were taken after 60 wks of age to determine the exterior and interior egg quality parameters. Eggs were weighed individually then broken and the inner contents were placed on a leveled glass surface to determine the inner egg quality. Shell weight \% (SW), shell thickness, mm (ST) including shell membranes were measured using a micrometer at three locations on the egg (air cell, equator and sharp end). Records were also taken for egg length, mm (EL), egg width, mm $(\mathrm{EWd}$ ), shape index (SI) (estimated as the percentage of EWd to EL), albumen weight \% (AW), yolk weight \% (YW), yolk height, $\mathrm{mm}(\mathrm{YH})$, yolk diameter, $\mathrm{mm}$
(YD) and yolk index (YI) (estimated as the percentage of YH to YD).

\section{Carcass traits:-}

At the end of the experimental period (60 wks of age), six birds ( 3 cocks +3 hens) from each treatment were randomly chosen, weighed and slaughtered until complete bleeding and feathers were removed. The birds were weighed after removing heads, legs and viscera to determine the percentage of carcass weight included wings and necks. The heart, liver, empty gizzard, as well as oviduct length $(\mathrm{cm})$, ovary, oviduct, testes and abdominal fat were separated, weighed and their relative weight to live body weight were calculated.

\section{Blood biochemical analysis and hematological picture:-}

At 60 weeks of age (end of experiment), blood samples were collected from each slaughtered bird during exsanguination in two heparinized test tubes. Blood of the first tube was used to evaluate the total count of red and white blood cells as well as the differential counts of leucocytes (lymphocyte and heterophil) while, the second one was centrifuged at $3000 \mathrm{rpm}$ for 20 minutes. The separated plasma was stored at $-20^{\circ} \mathrm{C}$ until being assayed for plasma sex hormones (testosterone, estrogen and progesterone) and plasma minerals ( $\mathrm{Ca}, \mathrm{P}, \mathrm{Zn}, \mathrm{Fe}$ and $\mathrm{Cu}$ ) according to the manufacture recommendations of commercial kits.

\section{Semen quality:}

Semen samples were collected randomly from 15 cocks ( 3 cocks of each treatment) at 60 weeks of age using the massage method. Semen samples were examined for the following characteristics, according to Kalamah et al. (2000).

1-The ejaculate volume was determined to the nearest $0.01 \mathrm{ml}$. using $1.00 \mathrm{ml}$. tuberculin syringe.

2-Mass motility score (from 1 to 5 grades). 
3-Percentage of live and abnormal sperm was determined after staining with iosine and nigrosine.

4-Sperm concentration was determined by using Thomes - Zeis haemocytometer.

5-Total sperm/ejaculate $\times 109=$ (ejaculate volume x sperm concentration). 6-Total abnormal sperm/ejaculate x 109 $=($ sperm concentration $\mathrm{x}$ abnormal sperm\% / 100).

7-Total live sperm/ejaculate $\mathrm{x} 109=$ (sperm concentration $\mathrm{x}$ live sperm\% / 100).

The previous characteristics were determined according to (Kalamah et al., 2000).

\section{Histomorphological parameters:}

For histomorphological studies of male testicular tissues, three samples per treatment (right testes) were cut from the middle region of testes. Tissue samples were flushed and fixed in $10 \%$ neutral buffered formalin for $72 \mathrm{hrs}$. Samples were trimmed and processed into Paraplast tissue embedding media. 3-5 $\mu$ sections were cut by rotatory microtome. At least 6 cross sections per sample were cut (18 cross sections per treatment). The sections were stained with Harris Hematoxylin and Eosin as a general staining method as outlined by Bancroft and Stevens (2010). Tissue sections were examined for histomorphological studies under light microscope equipped with full HD microscopic camera and Image analysis software (Leica Microsystems, Germany). A total of 30 semi circular seminiferous tubules were randomly selected from different regions of the tissue sections per sample. Seminiferous tubule diameter and germinal epithelium thickness were measured by image analysis software for statistical analysis.

\section{Fertility and hatchability:}

A total of 500 eggs were incubated to calculate fertility at 60 weeks of age. Hatchability was calculated as a percentage of fertile eggs or of total eggs set.

\section{Statistical analysis:}

Data were subjected to one-way analysis of variance using SAS (2000). Differences among means were detected by using Duncan's multiple range test (Duncan, 1955). The percentage values were transferred to percentage angle using arcsine equation before subjected to statistical analysis, and then actual means are presented. The following model was used:

$\mathrm{Yij}=\mathrm{G}+\mathrm{Ti}+\mathrm{eij}$.

Where, Yij = observation for each dependent variable; $\mathrm{G}=$ General mean;

$\mathrm{Ti}=$ Treatment effects $(\mathrm{i}=1,2 \ldots$ and 5$)$; eij $=$ Random error.

\section{RESULTS}

\section{Laying performance traits:}

Effects of adding Zinc methionine levels to Inshas layer diets on productive performance traits during experimental period are shown in Table (2). All productive performance traits (Table 2) except feed consumption were improved by any level of Zinc supplementation throughout experimental period studied. Final body weight, body weight gain and egg production percentage were significantly $(\mathrm{P} \leq 0.05)$ improved for birds fed diet supplemented with Zinc methionine at levels 60,80 and $100 \mathrm{mg} / \mathrm{kg}$ diet (T3, T4 and T5 groups, respectively) also, feed conversion and egg mass at levels 40, 60, 80 and $100 \mathrm{mg} / \mathrm{kg}$ diet (T2, T3, T4 and T5 groups, respectively) were better than those fed the control diet (T1) group.

\section{Egg quality traits:}

No significant effect on both external egg quality (except shell thickness and shell weight percentage) and internal egg quality (except albumen weight percentage) was observed due to Zinc methionine levels addition to Inshas laying 
hen diets (Table 3). Significant $(\mathrm{P} \leq 0.05)$ improvement was found in both shell thickness and shell weight percentage of hens supplemented with Zinc methionine at levels 60,80 and $100 \mathrm{mg} / \mathrm{kg}$ diet (T3, T4 and T5 groups) and in albumen weight percentage at levels 40, 60, 80 and $100 \mathrm{mg} / \mathrm{kg}$ diet (T2, T3, T4 and T5 groups) compared to those fed the control diet (T1).

\section{Carcass traits and reproductive organs:-}

As shown in Table (4), adding Zinc methionine to Inshas laying hens and cocks diets had insignificant effect on oviduct length, relative ovary and abdominal fat weights for Inshas laying hens and relative liver, heart, gizzard and dressing weights for both Inshas laying hens and cocks, but the relative oviduct weight of Inshas lying hens and relative testes weight of Inshas cocks showed gradual increase as dietary Zinc methionine levels increased with significantly $(\mathrm{P} \leq 0.05)$ effect between $\mathrm{T} 5$ group only and $\mathrm{T} 1$ (control) group for relative oviduct weight and between both $\mathrm{T} 5$ and $\mathrm{T} 4$ groups and T1 (control) group for relative testes weight.

\section{Blood hematological picture:}

The results in Table (5) showed gradual increase in hemoglobin $(\mathrm{Hb})$, red blood cells (RBCs), hematocrit, white blood cells (WBCs) and lymphocyte percentage and gradual decrease in heterophill/lymphocyte ratio with increasing dietary levels of Zinc methionine compared to control group. Zinc methionine groups had significant $(\mathrm{P} \leq 0.05)$ higher red blood cells (RBCs), white blood cells (WBCs) numbers and lymphocyte percentage in (T5) group that fed $100 \mathrm{mg}$ Zinc methionine/kg diet compared to control group. The increase in RBC's number was accompanied with a significant increase in hemoglobin $(\mathrm{Hb})$ concentration in the same treatment (T5) group. Response of hematocrit values to the different treatments followed the same trend observed for RBC's number and $\mathrm{Hb}$ concentrations. Moreover, the best and significant $\quad(\mathrm{P} \leq 0.05) \quad$ value of heterophill/lymphocyte ratio was recorded by (T5) then (T4) groups compared with (T1) group (control) which had the worst value.

\section{Blood biochemical analysis:- a- Plasma minerals:-}

As shown in Table (6), adding Zinc methionine to laying hens diet did not significantly affect plasma phosphorus $(\mathrm{P})$, Copper $(\mathrm{Cu})$ and Iron $(\mathrm{Fe})$ concentrations compared to the control group but, slight gradual decrease (without harmful effect on performance traits) was observed with increasing dietary Zinc methionine levels. While, adding Zinc methionine to laying hens diet significantly $(\mathrm{P} \leq 0.05)$ increased plasma Zinc (Zn) concentrations comparing to untreated group (control) and the highest level of plasma Zinc was recorded for the highest level of Zinc methionine in laying hens diet ( T5) group.

\section{b- Plasma sex hormones:}

Data of blood plasma sex hormones as affected by different levels of Zinc methionine during experimental period are presented in Table (7) Plasma testosterone, estrogen and progesterone hormones concentration were linearly increased with increasing dietary Zinc methionine levels, the highest and significant $(\mathrm{P} \leq 0.05)$ value was recorded for level $100 \mathrm{mg}$ Zinc methionine $/ \mathrm{kg}$ diet (T5) group compared to control group which had the lowest value.

\section{Semen quality:}

Data of the semen physical characteristics at 60 wks of age are shown in Table (8). Supplementation of Zinc methionine to cock's diet at different levels caused a significant $(\mathrm{P} \leq 0.05)$ effect on all semen physical characteristics studied except semen $\mathrm{pH}$. The values of ejaculate volume (E.V), sperm concentration (S.C), live sperm percentage (L.S\%), sperm motility 
(S.M), total sperm per ejaculate (TS/E) and total live sperm per ejaculate (TLS/E) were increased but abnormal sperm percentage (Ab.S\%) and total abnormal sperm per ejaculate (TAbS/E) were decreased as the levels of Zinc methionine in cocks diet increased compared to cocks of control group.

\section{Histomorphological parameters:}

In Table (9) and Fig (1), Microscopic analysis of seminiferous tubules from different treatments showed that highest and significant $(\mathrm{P} \leq 0.05)$ seminiferous tubular diameter is found to be in T5 then T4 groups with nearly $49.8 \%$ and $42.7 \%$ more than the control group respectively. Germinal epithelium thickness was significantly $(P \leq 0.05)$ increased gradually as levels of Zinc methionine in cock's diet increased compared to cocks of control group and T5 group demonstrated about $45 \%$ thicker than control group.

\section{Fertility and hatchability:}

Significant effects of Zinc methionine treatment on fertility and hatchability percentages are shown in Table (10). Both fertility percentages, hatchability percentage of total eggs and hatchability percentage of fertile eggs were significantly $(\mathrm{P} \leq 0.05)$ higher in Zinc methionine treated groups except (T2) group which was insignificantly higher compared to the control group. In general the values of all previous mentioned traits were increased gradually by increasing dietary Zinc methionine levels.

\section{DISCUSSION}

All productive performance traits (body weight gain, feed conversion, egg production percentage and egg mass) except feed consumption increased linearly with increasing dietary levels of Zinc may be due to that Zinc 1) increases insulin concentration (Zinc is a component of insulin) which regulates metabolism of carbohydrate, fat, and protein, stimulating amino acid uptake and protein synthesis as well as glucose utilization in tissues thus, improving body weight gain (Linder, 1991); 2) increases blood nitric oxide (NO) concentrations which has been postulated to regulate follicular development, ovulatory mechanisms thereby increasing egg production because there are an association between the size of ovarian follicles and NO metabolites (nitrite and nitrate) (Manwar et al., 2006); 3 ) inhibits the activity of microbial urease, a key enzyme converting nitrogen compounds in the manure into ammonia and the later reduce feed efficiency, growth rate, and egg production (Kim and Patterson, 2005); 4) protects from lipid peroxidation due to the following reasons: First) its direct antioxidant action by occupying iron- and copper-binding sites in lipids, proteins, and DNA for preventing them from binding to cells membranes thereby decrease the production of free radicals, thus exerting a direct antioxidant action (Tate et al., 1999); Second) is a structural part of superoxide dismutase enzyme (cofactor), this enzyme scavenging superoxide radicals in the presence of zinc (Zago and Oteiza, 2001) ; Third) stimulate glutathione peroxidase enzyme which react directly with reactive oxygen species ( ROS), (Atakisi et al., 2009), this ROS widely produced by cell metabolism and react with double bonds of polyunsaturated fatty acids to yield lipid hydro peroxides thus cause tissue damage (Halliwell and Gutteridge 1984) and Fourth) increases the synthesis of metallothioneines (zinc binding proteins) which consider a class of antioxidants acts as a free radical scavenger (Ebadi et al.,1996). Thereby, through its previous role (as antioxidants) may protects hepatic cell's membranes from oxidative damage (Faa, et al., 2008), thus, may enhance synthesis of egg yolk precursors (vitellogenin and very low density lipoprotein) in the liver thereby 
increasing egg production. This concept is confirmed by (Bollengier-Lee et al., 1998) who demonstrated that Vit.E (through its action as an anti-oxidant) protects the liver from lipid peroxidation and the damage of its cell membranes, enhancing synthesis of egg yolk precursors (vitellogenin and very low density lipoprotein) in the liver, facilitating the release of the previous precursors from the liver and increasing the circulating supply of them for yolk formation thereby increasing egg production. 5) is an essential component of both DNA and RNA polymerase enzymes (DNA synthesis), as an integral part of more than 300 enzyme systems that are involved in metabolism of energy, carbohydrates, nucleic acids and protein and its deficiency may lead to retarded growth, reduced feed efficiency and even death in severe cases (Vallee and Falchuk 1993). And 6) commercially available Zinc methionine complexes provide both Zinc and methionine, because Zinc methionine complexes are transported intact from the intestinal lumen into the mucosal cells and absorbed without modification thus, provide tissues with methionine which should improve animal productivity as well as the role of Zinc (as mentioned above) (Hill et al., 1986 and Hempe and Cousins, 1989). Our results are in harmony with (Kim and Patterson, 2005) who observed an improvement in egg production for layers fed organic Zinc. Also, Bahakaim et al. (2014) found that the highest and significant overall mean of egg mass was observed for 100 then 50 $\mathrm{mg}$ Zinc methionine supplementation to layer's diet compared to control group.

The significant $(\mathrm{P} \leq 0.05)$ improvement in both shell thickness and shell weight percentage with Zinc methionine at levels 60,80 and $100 \mathrm{mg} / \mathrm{kg}$ diet and in albumen weight percentage at levels 40, 60, 80 and $100 \mathrm{mg} / \mathrm{kg}$ diet compared to those fed the control diet may be due to the importance of Zinc function in the formation of egg.
In this respect, Nys et al.(1999) indicated that Zinc plays an important role in the isthmus and uterus where egg shell membranes and egg sell formation are produced respectively, because Zinc is dependent enzyme (cofactor) of carbonic anhydrase enzyme which plays a role in converting calcium into calcium carbonate which is needed for egg shell formation and inhibition of this enzyme results in lowered bicarbonate ion secretion and, consequently, greatly reduces egg shell weight and thickness Also, Williams, (1997) and Zinpro, (2002) indicated that Zinc plays an important role in protein synthesis in the magnum during the deposition of albumen. Our results are in harmony with the finding of Mabe et al. (2003) who showed an improvement in egg shell quality by using $60 \mathrm{mg}$ zinc methionine $/ \mathrm{kg}$ diet of laying hens' basal diet. Also, Albumen weight in group of hens received $50 \mathrm{mg}$ organic Zinc/kg layer diet tended to increase significantly (Tabatabaie et al., 2007).

Regarding to hematological picture, gradual increase in both hemoglobin $(\mathrm{Hb})$, red blood cells (RBCs), hematocrit, white blood cells (WBCs) and lymphocyte percentage and gradual decrease in heterophill/lymphocyte ratio with increasing dietary levels of Zinc methionine compared to control group may be due to that Zinc 1) plays an important role in incorporation of iron into the hemoglobin (Parák, and Straková, 2011), thereby increasing hemoglobin which reflects on increasing red blood cells and hematocrit and 2) is required for the development of lymphocytes (Kidd et al, 1996) which leading to First), increasing white blood cells and Second), decreasing heterophill/lymphocyte ratio thereby, alleviated stress because exposure to stress (aging in our study) would increase the ratio progressively whereas, heterophill/lymphocyte ratio accepted as a reliable and accurate physiological 
indicator of stress response in chickens (Gross and Siegel, 1983). These findings are similar to the conclusions drawn by (Chitithoti et al., 2012) who found that Zinc-methionine at levels $(60$ or $80 \mathrm{mg} / \mathrm{kg}$ diet) resulted in a significant reduce in heterophill/lymphocyte ratio in compare with the control which indicate that, supplementation of zinc at these levels was useful in reducing stress in broilers.

Concerning to blood minerals, plasma Phosphorus, Copper and Iron concentrations had gradually insignificant decreased (slight decrease), but plasma Zinc gradually increased significantly $(\mathrm{P} \leq 0.05)$ as the levels of dietary zinc methionine increased, this may be due to that Zinc methionine (organic source) has more availability compared to inorganic source like zinc sulphate or oxide because the ring structure of organic minerals neutralizes the positive charge of metal ion and protects the mineral from unwanted interactions with other nutrients in the gastrointestinal tract thereby, pass intact through the intestinal wall into the blood stream, and absorbed more efficiently than inorganic source which reflect on increasing plasma Zinc (Wedekind et al., 1992 and Miles and Henry, 1999 ). But, the slight decrease (without harmful effect on performance traits) of Phosphorus, Copper and Iron may be due to depression in their uptake in the stomach and duodenum and higher fecal excretion of them because of the antagonistic interactions between Zinc and other minerals (Sunder et al., 2008). These results are in harmony with (Sajadifar, 2013) who found that increasing dietary Zinc level (40, 120 and $200 \mathrm{mg} / \mathrm{kg}$ ) of broiler chicks resulted in significant $(\mathrm{p} \leq 0.05)$ decrease of blood Phosphorus and Copper concentration.

As regard to sex hormones, plasma testosterone, estrogen and progesterone hormones concentration were linearly increased with increasing dietary zinc methionine levels because Zinc stimulates the releasing of gonadotropic hormones which in males, are responsible for testosterone externalization from testis's interstitial cells (leydig cells) and in females, stimulate pituitary follicle stimulating hormone (FSH) and luteinizing hormone (LH) which reflect on increasing both estrogen and progesterone hormones and egg production (Favier, 1992), in line with this, is our previous finding of increasing egg production (Table 2). Likewise, these results are in accordance with those of (Amen and AlDaraji 2011) who found that adding Zinc levels (50, 75 and $100 \mathrm{mg} /$ diet) to Cobb 500 broiler breeder resulted in significant increase in both plasma testosterone hormone concentrations at 54, 58 and 66 weeks of age and plasma estrogen and progesterone hormones concentrations at 54 and 66 weeks of age as compared with control group.

The values of sperm motility (S.M), ejaculate volume (E.V), sperm concentration (S.C), live sperm percentage (L.S\%), total sperm per ejaculate(TS/E) and total live sperm per ejaculate (TLS/E) were increased as levels of Zinc methionine in cock's diet increased compared to cocks of control group because Zinc plays an important role in the development of the flagellar system of the sperm through activates enzyme controlling flagellar system which is leading to increase sperm motility and the motility is essential for sperm to traverse the vagina and reach the sperm storage tubules which is important for increasing fertility (Caldomone et al.,1979). As mentioned above, Zinc increases testosterone hormone (Favier, 1992) and the latter is required to complete meiosis and spermatids differentiation (Sharpe, 1994), thereby increasing sperm production and testicle growth (Fernandez, 
2008), which also in harmony with our results of increasing testes weight percentage in Table (4). This concept is confirmed by Jianguo and Zhinian, (1990) who said that testosterone concentration in serum was positively correlated with semen quality and our findings are in agreement with Amen and Al-Daraji, (2011) who found significant increase in semen volume for Cobb 500 broiler breeder groups received dietary Zinc levels (75 and $100 \mathrm{mg} / \mathrm{diet}$ ) compared to control group at 50, 54, 62 and 66 weeks of age, moreover, Moce et al. (2000), registered higher volumes ejaculates of rabbits with increasing dietary Zinc levels from 35 to $100 \mathrm{ppm}$.

Abnormal sperm percentage (Ab.S\%) and total abnormal sperm per ejaculate (TAbS/E) which were decreased by increasing zinc methionine levels in cock's diet compared to cocks of control group may be due to that Zinc helps in protecting the structure of the genetic material (DNA chromatin in the sperm nucleus) (Bjorndahl, et al., 1991), and high Zinc concentrations play an important role in preventing lipid peroxidation of the long chain polyunsaturated fatty acids in the sperm cell membrane (Cecil and Bakst, 1993).

Respecting histomorphological parameters of male testicular tissue, germinal epithelium thickness was significantly $(\mathrm{P} \leq$ 0.05) increased gradually as levels of Zinc methionine in cock's diet increased compared to cocks of control group, this may be due to, as mentioned above, Zinc increases testosterone hormone from testis's interstitial cells (leydig cells) (Favier, 1992) and the latter is required to complete meiosis and spermatids differentiation (Sharpe, 1994), thereby increasing Germinal epithelium thickness because in birds, testosterone enhances Sertoli cells function to hold mature spermatozoa in place in the seminiferous tubules and regulate the release of the sperm cells (Rosenstrauch et al., 1994), which leading to increasing Germinal epithelium thickness and the later reflect (with increasing) on seminiferous tubules diameter because Seminiferous tubules are lined with a germinal epithelial layer showing different stages of the active spermatogenic cells resting on a basement membrane. This concept is confirmed by Thurston and Korn (2000) who reported significant positive correlation between testosterone concentration in blood plasma and Sertoli cells numbers and function. In this respect, Sharpe, (1994) found a positive correlation between Sertoli cells number and germinal cell numbers. Our results are in accordance with Al-Daraji and Amen, (2012) who revealed that adding zinc to the diet of broiler breeder males (50, 75 and $100 \mathrm{mg}$ zinc/kg of diet) resulted in a significant increase of relative testes weight, seminiferous tubules diameter and germinal cells thickness in comparison to the control group.

Values of fertility percentage, hatchability percentage of total eggs and hatchability percentage of fertile eggs were increased gradually by increasing dietary zinc methionine levels compared to control group, this may be due to that, First) Zinc has an important role on depressing oxygen uptake in the sperm cell therefore, Zinc may function as a metabolic inhibitor and regulate the phospholipids energy reserves thus, prolonging survivability of sperm in the sperm storage tubules and increasing the average number of sperm holes in the yolk layer leading to increasing fertility (Bakst,1985 and Brown and Pentland, 2007) and Second) following contact with the oocyte, Zinc removal from sperm appears to be involved in penetration and fertilization because Zinc contributes to the stable attachment of sperm head to tail, and its removal induces head-tail detachment (Bjorndahl and Kvist, 1982) which may be lead to increasing fertility percentage with 
increasing dietary Zinc methionine levels. This concept is confirmed by (Kvist, 1980) who said that head-tail attachment/deattachment and nuclear chromatin condensation/decondensation are also influenced by seminal zinc. Moreover, Zinc is required for the development of the avian embryo (Richards, 1997). Thus, may be increasing hatchability percentage with increasing dietary Zinc methionine levels, which in accordance with Rubin and Koide (1973) who said that Zinc is needed for cell division and multiplication. Our findings are similar to the conclusions drawn by Kidd et al. (1992) who found an increasing in the fertility of mature broiler breeder fed diet supplemented with $\mathrm{Zn}$-amino acid complex compared with a control diet. Also, Kout EI-Kloub, et al. (2004) reported that laying hens received diets supplemented with levels of either 100 or $150 \mathrm{mg}$ Zinc methionine $/ \mathrm{kg}$ diet resulted in significantly higher fertility percentage. Data from the current study, it could be conclude that Zinc methionine supplementation at $100 \mathrm{mg} / \mathrm{kg}$ diet was the best level and effective for decreasing oxidative stress of aging (Heterophill/Lymphocyte ratio), increasing productive, reproductive performance respecting sex hormones (testosterone, estrogen and progesterone) and some histological traits of testes. Therefore, adding zinc methionine with $100 \mathrm{mg} / \mathrm{kg}$ diet could be used as an efficient tool for improving productive, reproductive and physiological performance of male and female aged Inshas strain laying hens. 
Table (1): The composition of the experimental basal diet.

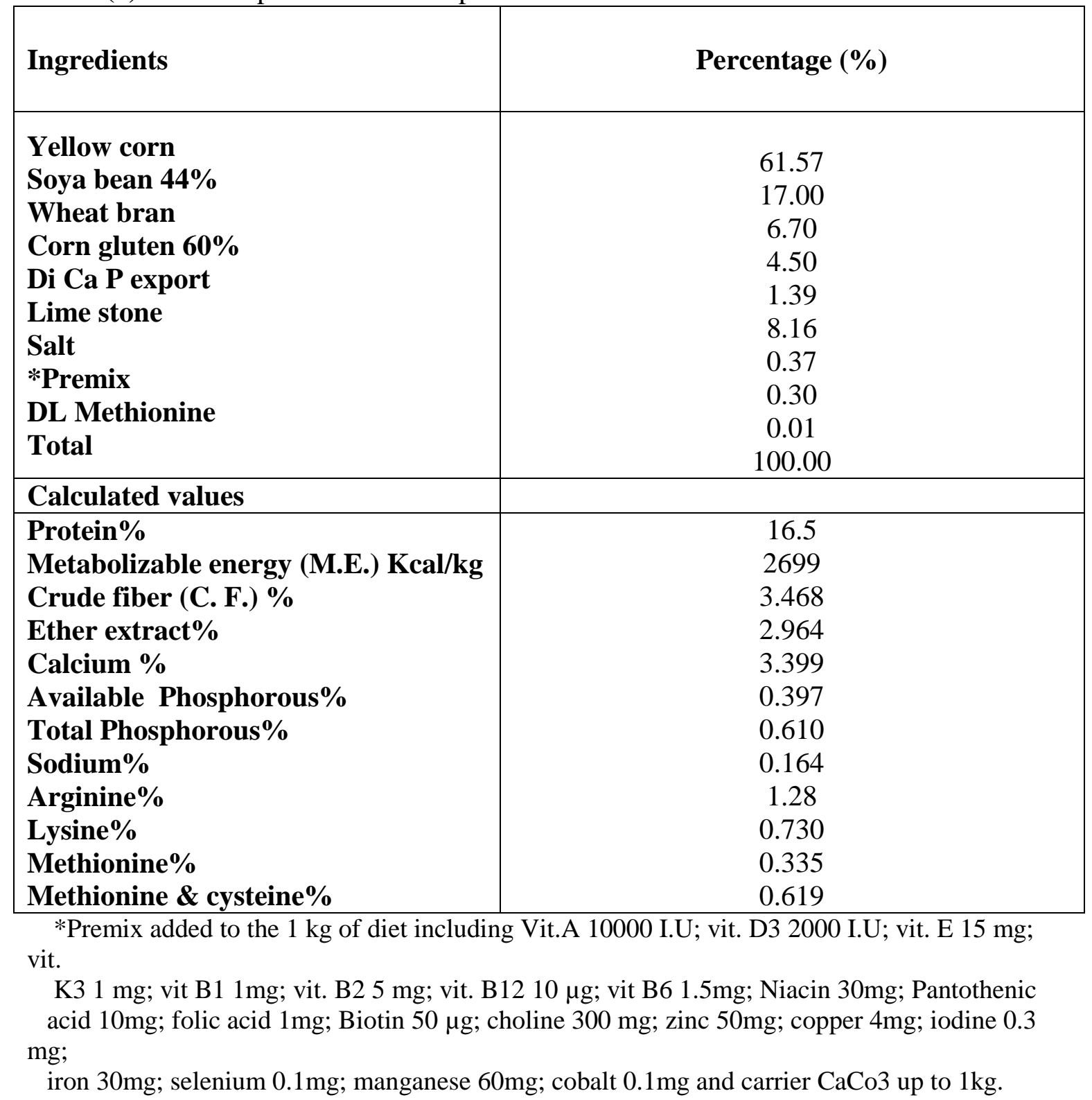


Table (2): Effect of dietary zinc methionine supplementation on the performance of Inshas laying hens during the experimental period.

\begin{tabular}{|c|c|c|c|c|c|c|}
\hline Item & T1 & T2 & T3 & T4 & T5 & SEM \\
\hline Initial body weight (g) & 1409.42 & 1404.94 & 1395.87 & 1417.27 & 1403.97 & 23.028 \\
\hline Final body weight (g) & $1531.09^{b}$ & $1548.45^{\mathrm{ab}}$ & $1582.39^{a}$ & $1619.18^{\mathrm{a}}$ & $1632.04^{\mathrm{a}}$ & 21.545 \\
\hline body weight gain (g) & $121.67^{b}$ & $143.51^{\mathrm{ab}}$ & $186.52^{\mathrm{a}}$ & $201.91^{\mathrm{a}}$ & $228.07^{\mathrm{a}}$ & 26.800 \\
\hline $\begin{array}{l}\text { Total feed intake } \\
\text { (g/hen/period) }\end{array}$ & 8340.36 & 8284.08 & 8211.52 & 8176.96 & 8102.60 & 35.726 \\
\hline $\begin{array}{l}\text { Feed conversion (g } \\
\text { feed/g egg mass) }\end{array}$ & $3.78^{a}$ & $3.46^{b}$ & $3.36^{\mathrm{bc}}$ & $3.27^{\mathrm{bc}}$ & $3.08^{\mathrm{c}}$ & 0.111 \\
\hline Egg number (egg) & $44.01^{b}$ & $47.69^{a b}$ & $48.48^{a b}$ & $49.40^{\mathrm{a}}$ & $51.62^{\mathrm{a}}$ & 1.521 \\
\hline Egg production (\%) & $52.40^{\mathrm{b}}$ & $56.78^{a b}$ & $57.71^{\mathrm{a}}$ & $58.81^{\mathrm{a}}$ & $61.45^{\mathrm{a}}$ & 1.811 \\
\hline Egg weigh (g/day) & 50.12 & 50.29 & 50.47 & 50.70 & 50.93 & 0.379 \\
\hline Egg mass (g/period) & $2205.46^{\mathrm{c}}$ & $2398.02^{b}$ & $2446.40^{b}$ & $2504.00^{\mathrm{ab}}$ & $2629.12^{\mathrm{a}}$ & 67.958 \\
\hline
\end{tabular}

a, b.... Means within each row have no similar letter(s) are significantly different $(\mathrm{P} \leq 0.05)$

T1:Control T2: zinc methionine $(40 \mathrm{mg} / \mathrm{kg})$ T3: zinc methionine $(60 \mathrm{mg} / \mathrm{kg})$ T4: zinc methionine $(80 \mathrm{mg} / \mathrm{kg})$ T5: zinc methionine $(100 \mathrm{mg} / \mathrm{kg})$.

Table (3): Effect of dietary zinc methionine supplementation on external and internal egg quality of Inshas laying hens at 60 weeks of age.

\begin{tabular}{|c|c|c|c|c|c|c|}
\hline Item & T1 & T2 & T3 & T4 & T5 & SEM \\
\hline \multicolumn{7}{|l|}{ External egg quality } \\
\hline Egg length (mm) & 54.15 & 53.78 & 53.02 & 53.33 & 53.20 & 0.894 \\
\hline Egg width (mm) & 40.43 & 41.22 & 41.55 & 40.77 & 40.93 & 0.444 \\
\hline $\begin{array}{l}\text { Shell thickness } \\
\text { (mm) }\end{array}$ & $0.310^{b}$ & $0.311^{\mathrm{b}}$ & $0.352^{\mathrm{a}}$ & $0.358^{\mathrm{a}}$ & $0.371^{\mathrm{a}}$ & 0.010 \\
\hline Shell weight (\%) & $12.88^{b}$ & $13.01^{b}$ & $13.86^{\mathrm{a}}$ & $13.98^{\mathrm{a}}$ & $14.21^{\mathrm{a}}$ & 0.488 \\
\hline Egg shape index & 74.69 & 76.73 & 78.39 & 76.50 & 76.91 & 1.236 \\
\hline \multicolumn{7}{|l|}{ Internal egg quality } \\
\hline $\begin{array}{l}\text { Albumen height } \\
(\mathrm{mm})\end{array}$ & 5.20 & 4.20 & 4.65 & 4.13 & 4.96 & 0.395 \\
\hline Albumen (\%) & $50.48^{b}$ & $51.63^{\mathrm{a}}$ & $52.02^{\mathrm{a}}$ & $52.50^{\mathrm{a}}$ & $52.58^{\mathrm{a}}$ & 1.133 \\
\hline Yolk height (mm) & 15.63 & 15.87 & 15.56 & 14.68 & 15.69 & 0.348 \\
\hline Yolk diameter & 41.88 & 41.62 & 41.97 & 38.97 & 39.92 & 1.088 \\
\hline Yolk $(\%)$ & 36.64 & 35.36 & 34.12 & 33.52 & 33.21 & 1.134 \\
\hline Yolk index & 37.31 & 38.11 & 37.07 & 37.71 & 39.34 & 1.168 \\
\hline
\end{tabular}

a, b.... Means within each row have no similar letter(s) are significantly different $(\mathrm{P} \leq 0.05)$

T1:Control T2: zinc methionine $(40 \mathrm{mg} / \mathrm{kg})$ T3: zinc methionine $(60 \mathrm{mg} / \mathrm{kg})$ T4: zinc methionine $(80 \mathrm{mg} / \mathrm{kg})$ T5: zinc methionine $(100 \mathrm{mg} / \mathrm{kg})$. 
Table (4): Effect of dietary zinc methionine supplementation on carcass traits and organs weight (\% of body weight) of Inshas laying hens and cocks at 60 weeks of age.

\begin{tabular}{|c|c|c|c|c|c|c|}
\hline Item & T1 & T2 & T3 & T4 & T5 & SEM \\
\hline \multicolumn{7}{|c|}{ Inshas laying hens } \\
\hline Oviduct length (cm) & 60.67 & 62.00 & 64.00 & 65.33 & 71.33 & 5.422 \\
\hline Ovary weight (\%) & 2.573 & 2.613 & 2.660 & 2.733 & 2.833 & 0.081 \\
\hline Oviduct weight (\%) & $2.727^{\mathrm{b}}$ & $2.763^{b}$ & $2.840^{\mathrm{ab}}$ & $2.860^{\mathrm{ab}}$ & $2.933^{\mathrm{a}}$ & 0.083 \\
\hline Liver weight (\%) & 2.260 & 2.387 & 2.313 & 2.413 & 2.427 & 0.274 \\
\hline Heart weight (\%) & 0.423 & 0.440 & 0.453 & 0.443 & 0.467 & 0.036 \\
\hline Gizzard weight (\%) & 1.990 & 1.880 & 1.870 & 1.833 & 1.980 & 0.119 \\
\hline Dressing weight $(\%)$ & 64.98 & 65.02 & 68.74 & 64.03 & 68.86 & 2.741 \\
\hline Abdominal fat weight (\%) & 0.240 & 0.227 & 0.247 & 0.243 & 0.210 & 0.012 \\
\hline \multicolumn{7}{|c|}{ Inshas cocks } \\
\hline Testes & $1.863^{\mathrm{b}}$ & $1.940^{\mathrm{b}}$ & $2.110^{\mathrm{ab}}$ & $2.307^{\mathrm{a}}$ & $2.428^{\mathrm{a}}$ & 0.103 \\
\hline Liver weight $(\%)$ & 2.410 & 2.423 & 2.333 & 2.250 & 2.453 & 0.173 \\
\hline Heart weight (\%) & 0.547 & 0.533 & 0.520 & 0.620 & 0.570 & 0.037 \\
\hline Gizzard weight (\%) & 1.830 & 1.847 & 1.923 & 1.803 & 1.776 & 0.289 \\
\hline Dressing weight $(\%)$ & 74.09 & 71.00 & 71.79 & 71.51 & 72.28 & 6.724 \\
\hline
\end{tabular}

a, b.... Means within each row have no similar letter(s) are significantly different $(\mathrm{P} \leq 0.05)$

T1:Control T2: zinc methionine $(40 \mathrm{mg} / \mathrm{kg})$ T3: zinc methionine $(60 \mathrm{mg} / \mathrm{kg})$ T4: zinc methionine $(80 \mathrm{mg} / \mathrm{kg})$ T5: zinc methionine $(100 \mathrm{mg} / \mathrm{kg})$.

Table (5): Effect of dietary zinc methionine supplementation on hematological picture of Inshas laying hens at 60 weeks of age.

\begin{tabular}{|c|c|c|c|c|c|c|}
\hline Item & T1 & $\mathbf{T 2}$ & T3 & T4 & T5 & SEM \\
\hline Hemoglobin (g/dl) & $11.282^{\mathrm{c}}$ & $13.283^{b}$ & $13.300^{b}$ & $13.330^{b}$ & $14.637^{\mathrm{a}}$ & 0.337 \\
\hline Red blood cells (x 106/ul) & $2.205^{b}$ & $2.350^{\mathrm{ab}}$ & $2.550^{\mathrm{ab}}$ & $2.560^{\mathrm{ab}}$ & $2.727^{\mathrm{a}}$ & 0.138 \\
\hline Hematocrit & $34.967^{\mathrm{b}}$ & $36.883^{\mathrm{ab}}$ & $39.498^{\mathrm{a}}$ & $39.555^{\mathrm{a}}$ & $40.470^{\mathrm{a}}$ & 1.371 \\
\hline White blood cells (x 10³/ul) & $6.383^{b}$ & $6.750^{\mathrm{ab}}$ & $6.943^{\mathrm{ab}}$ & $7.163^{a b}$ & $7.680^{\mathrm{a}}$ & 0.333 \\
\hline Heterophill (\%) & 28.667 & 28.717 & 28.517 & 28.633 & 28.550 & 0.293 \\
\hline Lymphocyte (\%) & $51.830^{c}$ & $54.660^{\mathrm{bc}}$ & $54.978^{b c}$ & $57.672^{a b}$ & $59.950^{\mathrm{a}}$ & 1.325 \\
\hline $\begin{array}{l}\text { Heterophill/Lymphocyte } \\
\text { ratio }\end{array}$ & $0.554^{\mathrm{a}}$ & $0.525^{\mathrm{ab}}$ & $0.519^{a b}$ & $0.496^{b c}$ & $0.477^{\mathrm{c}}$ & 0.014 \\
\hline
\end{tabular}

a, b... Means within each row have no similar letter(s) are significantly different $(\mathrm{P} \leq 0.05)$

$\mathrm{T} 1$ :Control T2: zinc methionine $(40 \mathrm{mg} / \mathrm{kg})$ T3: zinc methionine $(60 \mathrm{mg} / \mathrm{kg}) \quad \mathrm{T} 4$ : zinc methionine $(80 \mathrm{mg} / \mathrm{kg})$ T5: zinc methionine $(100 \mathrm{mg} / \mathrm{kg})$. 
Table (6): Effect of dietary zinc methionine supplementation on blood plasma minerals of Inshas laying hens at 60 weeks of age.

\begin{tabular}{|l|c|c|c|c|c|c|}
\hline \multicolumn{1}{|c|}{ Item } & T1 & T2 & T3 & T4 & T5 & SEM \\
\hline Plasma P (mg/dl) & 5.92 & 5.85 & 5.76 & 5.63 & 5.46 & 0.126 \\
Plasma Cu (mg/dl) & 0.344 & 0.330 & 0.321 & 0.308 & 0.302 & 0.007 \\
Plasma Fe (mg/dl) & 312.20 & 309.40 & 304.60 & 295.40 & 293.40 & 6.980 \\
Plasma Zn (mg/dl) & $4.23^{\mathrm{b}}$ & $5.32^{\mathrm{a}}$ & $5.48^{\mathrm{a}}$ & $5.57^{\mathrm{a}}$ & $5.76^{\mathrm{a}}$ & 0.186 \\
\hline
\end{tabular}

a, b.... Means within each row have no similar letter(s) are significantly different $(\mathrm{P} \leq 0.05)$

T1:Control T2: zinc methionine $(40 \mathrm{mg} / \mathrm{kg})$ T3: zinc methionine $(60 \mathrm{mg} / \mathrm{kg})$ T4: zinc methionine $(80 \mathrm{mg} / \mathrm{kg}) \mathrm{T} 5:$ zinc methionine $(100 \mathrm{mg} / \mathrm{kg})$.

$\mathrm{P}=$ Phosphorus, $\mathrm{Cu}=$ Copper, $\mathrm{Fe}=$ Iron, $\mathrm{Zn}=\mathrm{Zinc}$

Table (7): Effect of dietary zinc methionine supplementation on blood plasma sex hormones of Inshas chickens at 60 weeks of age.

\begin{tabular}{|l|c|c|c|c|c|c|}
\hline \multicolumn{1}{|c|}{ Item } & T1 & T2 & T3 & T4 & T5 & SEM \\
\hline Testosterone (ng/ml) & $2.445^{\mathrm{b}}$ & $2.982^{\mathrm{ab}}$ & $3.045^{\mathrm{ab}}$ & $3.367^{\mathrm{ab}}$ & $4.433^{\mathrm{a}}$ & 0.241 \\
Estrogen (pg/ml) & $220.00^{\mathrm{b}}$ & $289.19^{\mathrm{ab}}$ & $315.62^{\mathrm{ab}}$ & $366.68^{\mathrm{ab}}$ & $426.05^{\mathrm{a}}$ & 50.764 \\
Progesterone (ng/ml) & $0.183^{\mathrm{b}}$ & $0.205^{\mathrm{b}}$ & $0.220^{\mathrm{b}}$ & $0.237^{\mathrm{b}}$ & $0.329^{\mathrm{a}}$ & 0.025 \\
\hline
\end{tabular}

a, b.... Means within each row have no similar letter(s) are significantly different $(\mathrm{P} \leq 0.05)$

T1:Control T2: zinc methionine $(40 \mathrm{mg} / \mathrm{kg})$ T3: zinc methionine $(60 \mathrm{mg} / \mathrm{kg})$ T4: zinc methionine $(80 \mathrm{mg} / \mathrm{kg})$ T5: zinc methionine $(100 \mathrm{mg} / \mathrm{kg})$.

Table (8): Effect of dietary zinc methionine supplementation on semen quality traits of Inshas cocks at 60 weeks of age.

\begin{tabular}{|c|c|c|c|c|c|c|}
\hline Item & T1 & $\mathbf{T 2}$ & T3 & T4 & T5 & SEM \\
\hline Ejaculate volume (ml) & $0.333^{\mathrm{c}}$ & $0.397^{\mathrm{b}}$ & $0.413^{a b}$ & $0.432^{\mathrm{a}}$ & $0.440^{\mathrm{a}}$ & 0.040 \\
\hline Semen pH & 7.63 & 7.50 & 7.65 & 7.67 & 7.48 & 0.211 \\
\hline Sperm motility (1-5) & $2.667^{\mathrm{b}}$ & $3.333^{\mathrm{ab}}$ & $3.500^{\mathrm{a}}$ & $3.833^{\mathrm{a}}$ & $4.000^{\mathrm{a}}$ & 0.440 \\
\hline Live sperm \% & $76.00^{\mathrm{b}}$ & $84.50^{\mathrm{ab}}$ & $87.17^{\mathrm{a}}$ & $89.83^{\mathrm{a}}$ & $91.00^{\mathrm{a}}$ & 2.952 \\
\hline Abnormal sperm \% & $18.00^{\mathrm{a}}$ & $15.00^{\mathrm{ab}}$ & $14.17^{\mathrm{b}}$ & $13.17^{b}$ & $11.50^{\mathrm{b}}$ & 1.146 \\
\hline Sperm concentration $\left(\times \mathbf{1 0}^{9}\right)$ & $2.908^{b}$ & $3.348^{\mathrm{ab}}$ & $3.550^{\mathrm{ab}}$ & $3.628^{\mathrm{ab}}$ & $3.817^{\mathrm{a}}$ & 0.237 \\
\hline Total sperm/ejaculate & $0.967^{\mathrm{b}}$ & $1.365^{\mathrm{ab}}$ & $1.457^{\mathrm{ab}}$ & $1.557^{\mathrm{a}}$ & $1.707^{\mathrm{a}}$ & 0.178 \\
\hline Total live sperm/ejaculate & $2.242^{b}$ & $2.905^{\mathrm{ab}}$ & $3.098^{\mathrm{a}}$ & $3.270^{\mathrm{a}}$ & $3.482^{\mathrm{a}}$ & 0.269 \\
\hline $\begin{array}{l}\text { Total abnormal } \\
\text { sperm/ejaculate }\end{array}$ & $0.517^{\mathrm{a}}$ & $0.495^{\mathrm{ab}}$ & $0.468^{b c}$ & $0.452^{c}$ & $0.435^{\mathrm{c}}$ & 0.041 \\
\hline
\end{tabular}

a, b.... Means within each row have no similar letter(s) are significantly different $(\mathrm{P} \leq 0.05)$

T1:Control T2: zinc methionine $(40 \mathrm{mg} / \mathrm{kg})$ T3: zinc methionine $(60 \mathrm{mg} / \mathrm{kg})$ T4: zinc methionine $(80 \mathrm{mg} / \mathrm{kg})$ T5: zinc methionine $(100 \mathrm{mg} / \mathrm{kg})$. 
Table(9): Effect of dietary zinc methionine supplementation on some histomorphological parameters of male testicular tissue of Inshas cocks at 60 weeks of age.

\begin{tabular}{|l|c|c|c|c|c|c|}
\hline \multicolumn{1}{|c|}{ Item } & T1 & T2 & T3 & T4 & T5 & SEM \\
\hline $\begin{array}{l}\text { Seminiferous tubular } \\
\text { diameter }(\boldsymbol{\mu})\end{array}$ & $211^{\mathrm{c}}$ & $241^{\mathrm{c}}$ & $260^{\mathrm{bc}}$ & $301^{\mathrm{ab}}$ & $316^{\mathrm{a}}$ & 6.81 \\
$\begin{array}{l}\text { Germinal epithelium } \\
\text { thickness }(\boldsymbol{\mu})\end{array}$ & $40^{\mathrm{b}}$ & $51^{\mathrm{a}}$ & $56^{\mathrm{a}}$ & $57^{\mathrm{a}}$ & $58^{\mathrm{a}}$ & 1.47 \\
\hline
\end{tabular}

a, b.... Means within each row have no similar letter(s) are significantly different $(\mathrm{P} \leq 0.05)$

T1:Control T2: zinc methionine $(40 \mathrm{mg} / \mathrm{kg})$ T3: zinc methionine $(60 \mathrm{mg} / \mathrm{kg}) \mathrm{T} 4$ : zinc methionine $(80 \mathrm{mg} / \mathrm{kg})$ T5: zinc methionine $(100 \mathrm{mg} / \mathrm{kg})$.

Table (10): Effect of dietary zinc methionine supplementation on fertility and hatchability percentages of Inshas laying hens at 60 weeks of age.

\begin{tabular}{|c|c|c|c|c|c|c|}
\hline Item & T1 & T2 & T3 & $\mathbf{T 4}$ & T5 & SEM \\
\hline Fertility (\%) & $85.55^{\mathrm{c}}$ & $87.61^{b c}$ & $89.77^{a b}$ & $89.84^{\mathrm{ab}}$ & $91.83^{\mathrm{a}}$ & 1.314 \\
\hline Hatchability of total eggs (\%) & $78.29^{b}$ & $81.14^{\mathrm{ab}}$ & $82.75^{\mathrm{a}}$ & $83.33^{\mathrm{a}}$ & $83.83^{\mathrm{a}}$ & 1.135 \\
\hline Hatchability of fertile eggs (\%) & $82.83^{c}$ & $86.17^{\mathrm{bc}}$ & $89.83^{\mathrm{ab}}$ & $91.00^{\mathrm{a}}$ & $93.33^{\mathrm{a}}$ & 1.496 \\
\hline
\end{tabular}

a, b.... Means within each row have no similar letter(s) are significantly different $(\mathrm{P} \leq 0.05)$

T1:Control T2: zinc methionine $(40 \mathrm{mg} / \mathrm{kg}) \mathrm{T} 3$ : zinc methionine $(60 \mathrm{mg} / \mathrm{kg}) \mathrm{T} 4$ : zinc methionine $(80 \mathrm{mg} / \mathrm{kg})$ T5: zinc methionine $(100 \mathrm{mg} / \mathrm{kg})$. 
Fig. (1) Showing the mean diameter of semi circular semineferous tubules in different groups (T1-T5). H\&E stain, X40.

T1:Control, T2: zinc methionine $(40 \mathrm{mg} / \mathrm{kg}), \quad \mathrm{T} 3$ : zinc methionine $(60 \mathrm{mg} / \mathrm{kg})$, T4: zinc methionine $(80 \mathrm{mg} / \mathrm{kg})$ and $\mathrm{T} 5$ : zinc methionine $(100 \mathrm{mg} / \mathrm{kg})$.
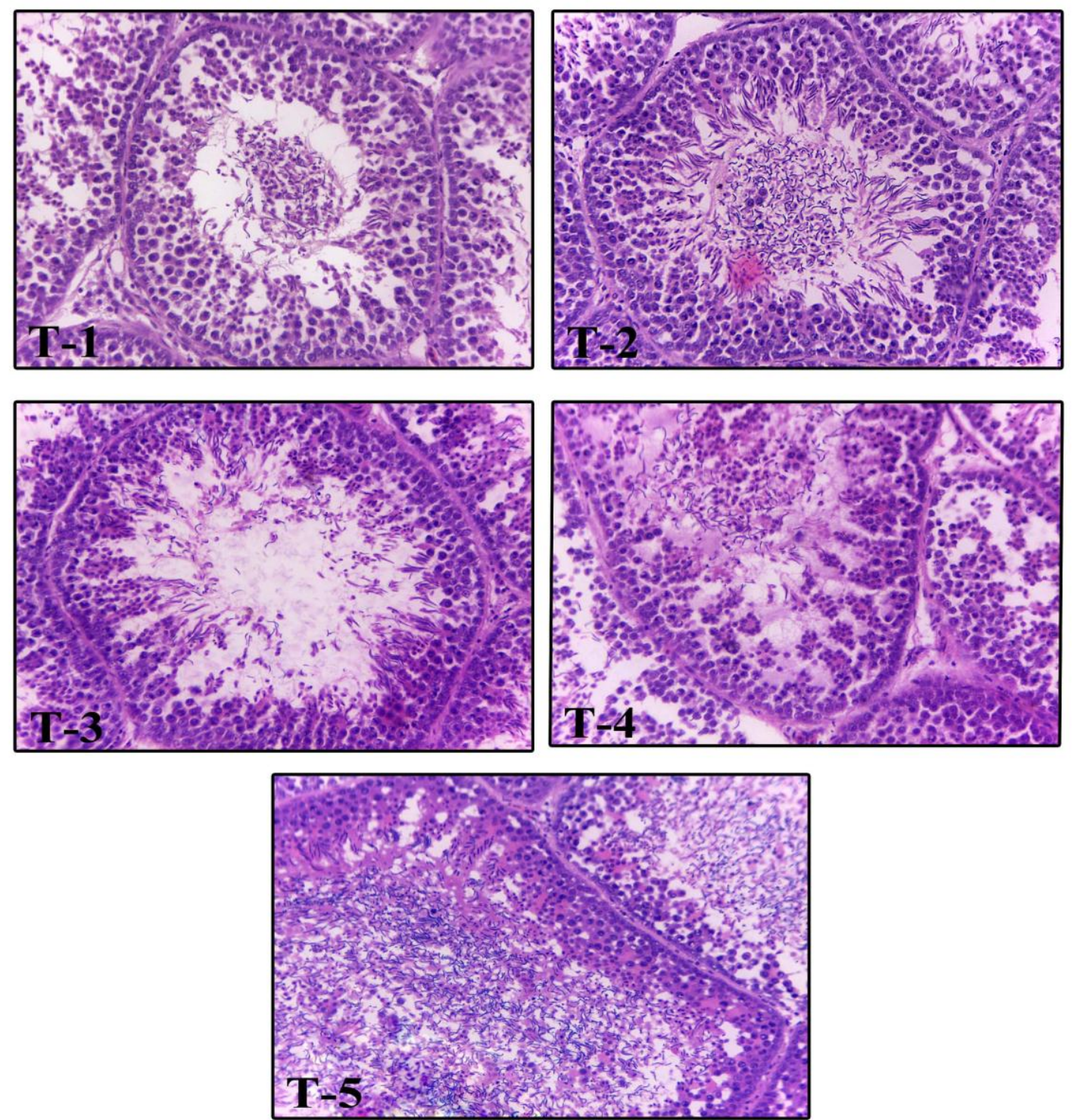


\section{REFERENCES}

Al-Daraji, H.J. and Amen, M.H.M. 2012. Effect of the supplementation of the broiler breeder males' ration with Zinc on histological Traits of Testes. International Journal of Applied Poultry Research, (91): 10-14.

Amen, M.H.M. and Al-Daraji, H.J. 2011. Influence of dietary supplementation with zinc on sex hormone concentrations of broiler breeder chickens. Pakistan Journal Nutrition, 10 (11): 1089-1093.

Atakisi, O.; Atakisi, E. and Kart, A. 2009. Effects of dietary Zinc and LArginine supplementation on total antioxidants capacity, lipid peroxidation, nitric oxide, egg weight, and blood biochemical values in Japanase quails. Biol. Trace Elem. Res., 132:136-143.

Bahakaim, A.S.A.; Abdel Magied, Hemat. A.; Osman, Sahar.M.H.; Omar, Amal S.; AbdelMalak, N.Y. and Ramadan, Nehad A. 2014. Effect of using different levels and sources of Zinc in layer's diets on egg Zinc enrichment. Egyptian Poultry Science Journal, 34: 3956.

Bakst, M.R. 1985. Zinc reduces turkey sperm oxygen uptake in vitro. Poultry Science, 64: 564-566.

Bancroft, O. D. and Stevens, A. 2010. Theory and Practice of Histological Technique. Chirchil Livingstone, Edinburgh, London and New york.

Bjorndahl, L. and Kvist, U. 1982. Importance of zinc for human head tail connection. Acta Physiol Scand, 116: 5155.

Bjorndahl, L.; Kjellberg, S. and Kvist, U. 1991. Ejaculatory sequence in men with low sperm chromatin - zinc. Int $\mathbf{J}$ Androl, 14: 174-178.

Bollengier-Lee, S.; Mitcliell, M.A.; Utom, D.B.; Williams, P.E. and Whitehead, C.C. 1998. Influence of high dietary vitamin E supplementation on egg production and plasma characteristics in hens subjected to heat stress. British Poultry Science, 39:106-112.

Boruta, A.; Swierczewska, E.; Glebocka, K. and Nollet, L. 2007. Trace organic minerals as a replacement of inorganic sources for layers: effects on productivity and mineral excretion. World Poultry Science Association, Proceedings of the 16th European Symposium on Poultry Nutrition, Strasbourg, France, 2630 August, 2007 pp. 491-494.

Brown, L. and Pentland, S. 2007. Health infertility organization: Male infertilityimproving sperm quality. Acubalance wellness. Centre Ltd. Onwest $8^{\text {th }}$ Ave. inVancouver Bc. Canada.

Burger, H.G.; Dudley, E.; Mamers, P.; Robertson, D.; Groome, N. and Dennerstein, L. 2002. The ageing female reproductive axis I. Novartis Found Symp., 242: 161-167.

Caldomone, A.A.; Freytag, M.K. and Cockett, A.T. 1979. Seminal zinc and male fertility. Urology, 13: 280-281.

Cecil, H.C. and Bakst, M.R. 1993. In vitro lipid peroxidation of turkey spermatozoa. Poultry Science,72: 13701378.

Chitithoti, A.K.; Venkata, R.J.; Jwalapu1, R.P.; Devanesan, S.S. and Satyanarayana Reddy, S.P. 2012. Immuno stimulatory effect of dietary supplementation of zinc sulphate and zincmethionine on immune response in broilers. Advances in Applied Science Research, 3 (5): 2785-2788.

Duncan, D.B. 1955. Multiple range and F. test. Biometric, (11): 1-42.

Ebadi, M.; Leuschen, M.P.; El Refaey, H.; Hamada, F.M.; Rojas, P. 1996. The antioxidant properties of zinc and metallothionein. Neurochem Int., 29:159166.

Edwards, H.M., and Baker, D.H. 1999.

Bioavailability of zinc in several sources 
of zinc oxide, zinc sulfate, and zinc metal. J. Anim. Sci., 77:2730-2735.

Faa, G.; Nurchi, W.M.; Ravarino, A.; Fanni, D.; Nemalato, S.; Gerosa, C.; Van Eyken, P. and Geboes, K. 2008. Zinc in gastrointestial and liver disease. Coordination Chemistry Reviews, 252:1257-1269.

Favier, A.E. 1992. The role of Zinc in reproduction: Hormonal mechanisms. Biol. Trace Element Research, 32: 363382.

Fernandez, M.M.F. 2008. Increase and decrease of sperm production. A potent penis. Los Angeles, California, USA.

Gross, W.B. and Siegel, H.S. 1983. Avian Diseases. Page, 972- 994.

Halliwell, B. and Gutteridge, J.M. 1984. Lipid peroxidation, oxygen radicals, cell demage and disease. Biochemical Journal, 219, 1-14.

Harman, D. 1992. Role of free radicals in aging and disease, Annual New York Acad. Sci. 673 126-141.

Hempe, J.M. and Cousins, R.J. 1989. Effect of EDTA and zinc methionine complex on zinc absorption by rat intestine. J. Nutr., 119:1179-1187.

Hill, D.A.; Peo, E.R.; Lewis, A.J. and Crenshaw, J.D. 1986. Zinc-amino acid complexes for swine. J. Anim. Sci., 63:121-130.

Jianguo, L. and Zhinian, I. 1990. Studies on the correlation between testosterone levels in serum and seminal plasma and semen quality. In 1 Stud Bull. J. Agric. Univ. Hebei, 2: 14-21.

Kalamah, M.A.; El-Nadi, M.M.; Goher, L.M. and Soliman, M.M. 2000. Some factors affecting fertility and hatchability using artificial insemination in Norfa chickens. $3^{\text {rd }}$ All Africa Conference on Animal Agric. and $11^{\text {th }}$ Conference of the Egyptian Society of Animal Production, Alex. Egypt, 6-9 November, 597-605.

Kidd, M.T.; Anthony, N.B.; Johnson, Z. and Lee, S. R. 1992. Effect of zinc methionine supplementation on the performance of mature broiler breeders. Journal Applied Poultry Research 1: 207211.

Kidd, M.T.; Ferket, P.R. and Qureshi, M.A. 1996. Zinc metabolism with special reference to its role in immunity. World's Poultry Science Journal, 52: 309-323.

Kim, W.K. and Patterson P.H. 2005. Effects of dietary zinc supplementation on hen performance, ammonia volatilization, and nitrogen retention in manure. Journal Environment Science, Health Part B 40:675-686.

Klasing, K.C. 1998. Comparative avian nutrition. University Pres at Cambridge UK.

Kout EI-Kloub M.E.; Hassan, R.A.; EIGanzory, E.H. and El-Abd, E. A. 2004. Effect of different sources and levels of zinc on the performance of local laying hens. Egyptian Poultry Science, 24:369385.

Kvist, U. 1980. Sperm nuclear chromatide condensation ability. An in vitro study on study ejaculated human spermatozoa. Acta Physiol Scand Suppl., 486: 1-24.

Linder, M.C. 1991. Nutrition and metabolism of the trace elements, in Nutritional Biochemistry and Metabolism with Clinical Applications, M.C. Linder, ed., Elsevier, New York, pp. 215-276.

Mabe, I.; Rapp, C.; Bain, M.M. and Nys, Y. 2003. Supplementation of corn soybean meal diet with manganese, copper and zinc from organic or inorganic sources improves egg shell quality in aged laying hens. Poultry Science, 82: 1903-1913.

Manwar, S.J.; Moudgal, R.P.; Sastry, K.V.; Mohan, J.; Tyagi, J.B.; Raina, R. 2006. Role of nitric oxide in ovarian follicular development and egg production in Japanese quail (Coturnix coturnix japonica). Theriogenology 65:1392-1400.

McDowell, L.R. 1992. Zinc. In: Cunha TJ (ed) Minerals in Animal and Human 
Nutrition, Academic, San Diego, CA, pp 265-293.

Miles, R.D. and Henry, P.R. 1999. Relative trace mineral bioavailability. Proceeding California Animal Nutrition Conference, Fresno, CA, pp. 1-24.

Moce, E.; Arouca, M.; Lavara, R. and Pascual, J.J. 2000. Effect of dietary Zinc and Vitamin supplementation on semen characteristics of high growth rate males during summer season. In: World Rabbit Congress, 7, Valencia. Proceedings. Valencia, Spain.

NRC. 1994. Nutrient Requirements of Poultry. 9th revised edition. National Academy Press, Washington, D.C., USA.

Nys, U.; Hincke, M.T.; Arias, J.L.; Garcia-Ruiz, J. M. and Solomon, S.E. 1999. Avian egg shell mineralization. Poult. Avian Biol. Rev., 10:143-166.

Ottinger, M.A. and Gorham, S.L. 1986. Histological and neuroendocrine correlates of the age related reproductive decline in male quail. Poultry Science, 65 (Suppl. 1): 100 (Abstr.).

Parák, T. and Straková, E. 2011. Zinc as a feed supplement and its impact on plasma cholesterol concentrations in breeding cocks. Acta Veterinary Brno.80: 281-285.

Richards, M.P. 1997. Trace mineral metabolism in the avian embryo. Poultry Science, 76: 152-164.

Rosenstrauch, A.; Degen, A.A. and Friedlander, M. 1994. Spermatozoa retention by sertoli cells during the decline in fertility aging roosters. Biol. Reprod., 50: 129-136.

Rubin, H. and Koide, T. 1973. Inhibition of DNA synthesis in chick embryo cultures by deprivation of Zinc. Journal Cell Biology, 56: 777-781.

Sajadifar, S. 2013. Effect of high levels of Zinc on plasma metalloenzymes activity and blood parameters in broiler chicks. Agriculture and Forestry, 59. (1): 99-106.
SAS Institute, Inc. 2000. SAS-User's Guide: Statistics. SAS Inst. Inc., Cary. NC.

Schipper, H.M. 2004. Brain iron deposition and the free radical mitochondrial theory of ageing. Ageing Res. Rev., 3: 265-301.

Sharpe, R.M. 1994. Regulation of spermatogenesis. In: The Physiology of Reproduction. (eds. E. Knobil and J. D. Neill), Raven Press, Ltd, New York, NY.

Sunder, G.S.; Panda, A.K.; Gopinath, N.C.S.; Rama Rao, S.V.; Raju, M.V.L.N.; Reddy, M.R.; Vijay Kumar, C.H. 2008. Effects of higher levels of zinc supplementation on performance, mineral availability and immune competence in broiler chickens. J. Appl. Poult. Res., 17: 79-86.

Tabatabaie, M.M.; Aliarabbi, H.; Ahmadi, A.A. and Hosseini Siyar, S.A. 2007. Effect of Different sources and levels of Zinc on egg quality and laying hen performance. Pakistan Journal of Biological Science, 10(19): 3476-3478.

Tate, D.J.; Miceli, M.V. and Newsome, D.A. 1999. Zinc protects against oxidative damage in cultured human retinal pigment epithelial cells. Free Radic. Biol.Med., 26: 704-713.

Thurston, R.J. and Korn, N. 2000. Spermatogenesis in commercial poultry species: Anatomy and control. Poultry Science, 79: 1650-1668.

Vallee, B.L. and Falchuk, K.H. 1993. The biochemical basis of Zn physiology. Physiol. Rev. 73: 79-118.

Wedekind, K.J.; Hortin, A.E. and Baker, D.H. 1992. Methodology for assessing zinc bioavailability: efficacy estimates for zinc-methionine, zinc sulfate, and zinc oxide. Journal of Animal Science, 70: 178-187.

Williams, K.C. 1997. Some factors affecting albumen quality particular reference to Haugh Unit Score. World's Poultry Science, Journal.,48:5 -16. 
Yu, B.P. and Yang, R. 1996. Critical evaluation of the free radical theory of aging. A proposal for the oxidative stress hypothesis, Ann. N.Y. Acad. Sci. 786: 111.

Zago, M.P. and Oteiza, P.I. 2001. The antioxidant properties of zinc: interactions with iron and antioxidants. Free Radic. Biol. Med., 31:266-274.

Zinpro,S.F.2002.Trace minerals for laying hens htt:/www.availzmc.com/ technical/layer/page $2 \mathrm{html}$.

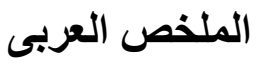

$$
\begin{aligned}
& \text { محاوله لتحسين الأداء الاتتاجى والتناسلى والفسيولوجى لأكور و اناث دجاج التهل الثاص البياض }
\end{aligned}
$$

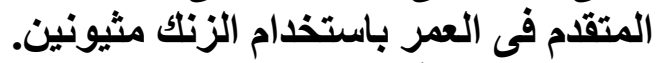

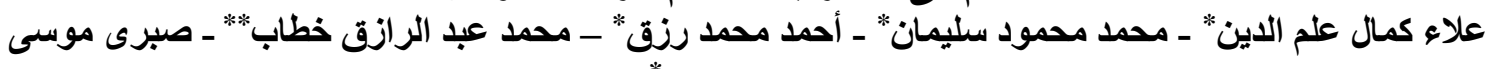

$$
\begin{aligned}
& \text { محمود موسنى } \\
& \text { * قسم بحوث تربية الدو اجن ـ معهد بحوث الانتاج الحيوانى ـ مركز البحوث الزر اعيه - وزارة الزر اعه ـدقى - جيزه }
\end{aligned}
$$

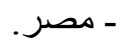

$$
\begin{aligned}
& \text { *** قسم الهستولوجى و الخلايا - كلية الطب البيطرى - جامعة القاهره - جيزه ـ مصر. }
\end{aligned}
$$

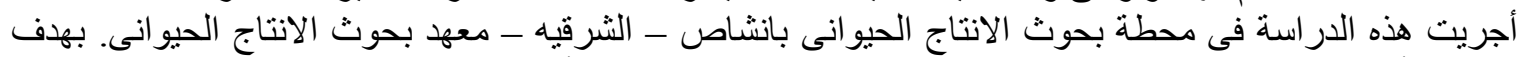

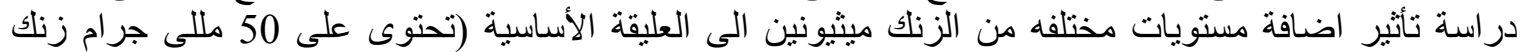

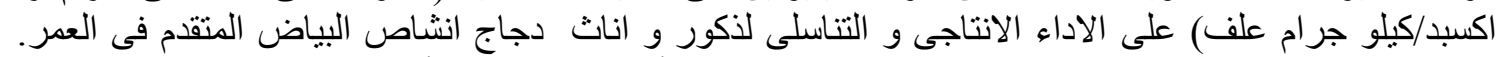

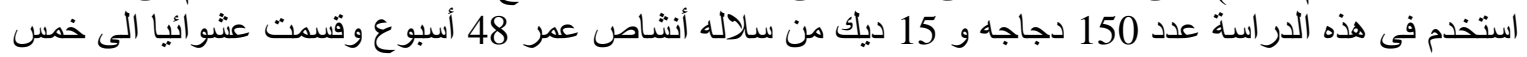

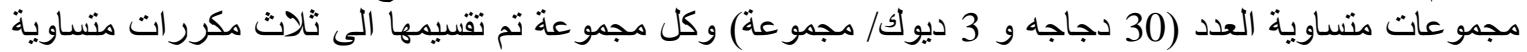

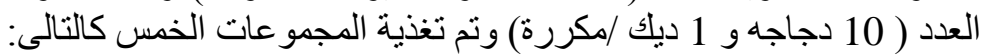

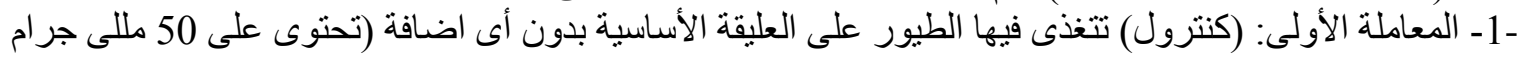
زناك اكسبد/كيلو جرام علف). 2 ـ المعاملة الثانيا: تتخذى فيها الطيور على العليقة الأساسية مضاف اليها الزنك مثيونين بمعدل 40 مللى جر ام / كجم عليقة. 3ـ المعاملة الثالثة: تتغذى فيها الطيور على العليقة الأساسية مضاف اليها الزنك مثيونين بمعدل 60 مللى جر ام / كجم عليقة. 4- المعاملة الر ابعة: تتخذى فيها الطيور على العليقة الأساسية مضاف اليها الزنك مثيونين بمعدل 80 مللى جرام / كجم عليقة. 5_المعاملة الخامسة: تتغذى فيها الطيور على العليقة الأساسية مضاف اليها الزنك مثيونين بمعدل 100 مللى جرام / كجم عليقة. إستمرت التجربه حتى عمر 60 أسبو ع وتتلخص أهم النتائج المتحصل عليها فيما يلى:

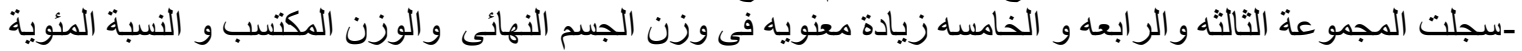

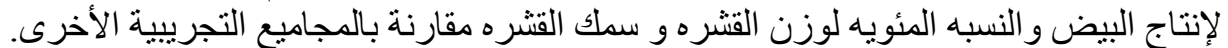

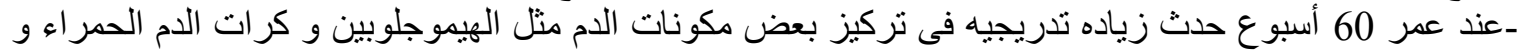

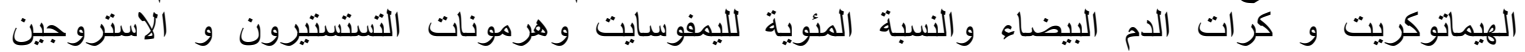

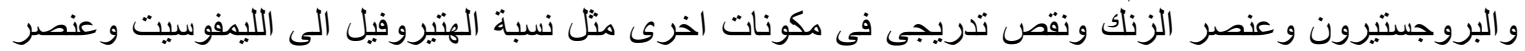

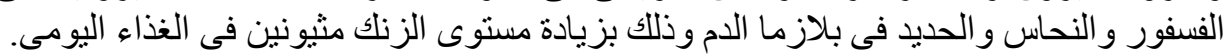

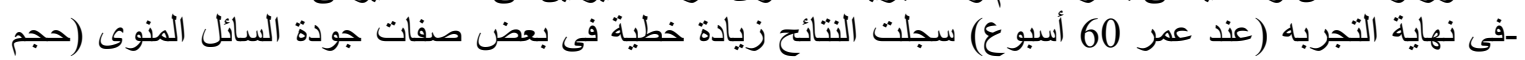

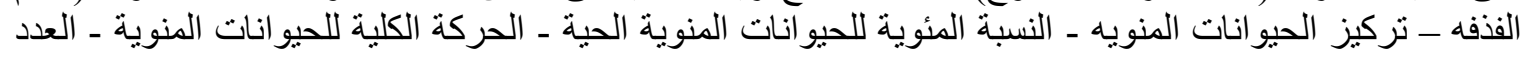

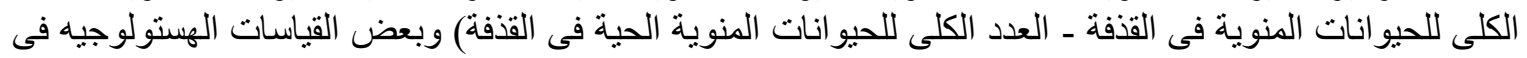

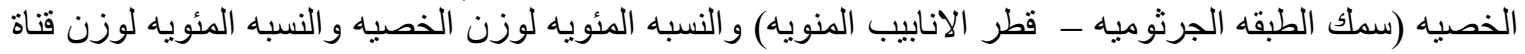

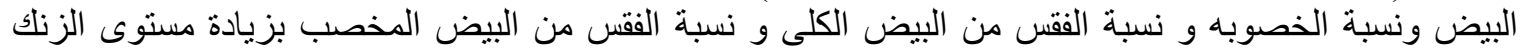

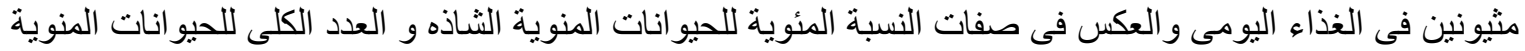
الثناذه فى القذفة.

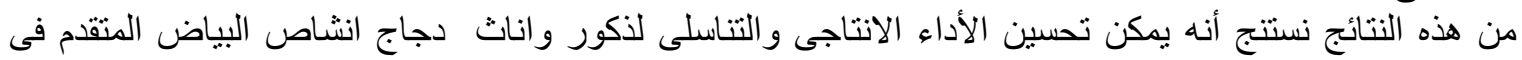
العمر باضافة 100 ملتجم زنك مثيونين /كجم عليقة. 